\title{
The Effect of Stakeholder's Pressure on Firm Performance and the Moderating Role of Perceived Economic Crisis
}

\author{
Mir Danial Mousavi ${ }^{1 *}$ and Mir Damoun Mousavi ${ }^{2}$ \\ ${ }^{1}$ Department of Business Administration, International Business, Allameh Amini Institute of \\ Higher Education, Mazandaran, Iran \\ ${ }^{2}$ Department of Business Administration, International Business, Nima Institute of Higher \\ Education, Mazandaran, Iran
}

\section{ARTICLE INFO}

Keywords:

Stakeholders pressure

Employee performance

Perceived economic crisis

\begin{abstract}
The stakeholder pressure is one of the institutional pressures, in this regard, organizations have their internal characteristics to match the expectations of key stakeholders in the environment. In the present study, the effect of stakeholder's pressure on firm performance was examined considering the moderating role of the perceived economic crisis. To investigate relationships, 208 questionnaires were collected from firms listed in the Tehran stock exchange. Structural equation modeling and PLS software were used to investigate the relationships. The results of this study showed that stakeholder's pressure has a positive effect on firm performance, and perceived economic crisis reduces firm performance, and when firms believe to more likely to be in crisis, the positive effect of stakeholder's pressure on firm performance was decreased.
\end{abstract}

\section{Introduction}

The concept of stakeholder after the publication of the book "Strategic Management: A Stakeholder Approach" has been endorsed in the literature, although its first appearance comes from a study by Stanford Research Institutes in 1963. The stakeholder is defined as any group or individual that can influence or be influenced by the goals of the organization (Freeman, 1984).

Stakeholder theory highlights that relationships with stakeholders can be managed effectively because successful business management is based on relationships and ways of working with stakeholders (Sarkaya, and Özdemir, 2009). In this sense, the theory suggests that the needs of the shareholders are not met before the needs of the stakeholders are met (Jamali, 2008). Moreover, by introducing new dimensions to the concept of share, this theory encompasses certain elements such as interests, demands, and rights, so the stakeholders may have legal rights besides ethical rights in the organization (Carroll \& Buchholtz, 2000).

The resource-based theory is a popular theoretical framework that can explain how stakeholders' pressure can affect organizations' performance (Jawahar \& Mclaughlin, 2001). This theory proposes that the internal resources of the firm can drive its sustainable competitive advantage (Kull, Mena, and Korschun, 2016). Thus, this perspective adopts an internal-based view, as opposed to an external-based view that a firm's competitive advantage derives from external market forces that can affect the ideal position of a company in a market (Porter and Millar, 1985). Based on this theory, the firms in an industry are heterogeneous in terms of the resources they have (Connor, 1991), so because of each firm has its unique resources, accessing to these resources is difficult and costly for other organizations (Kull, Mena, and Korschun,

\footnotetext{
* Corresponding author E-mail address: danial.msvi.mir@gmail.com 
2016). Therefore, an organization is not autonomous or self-sufficient, and it depends on the stakeholders as its resources (Pfeffer \& Salansky, 1978). This dependency allows stakeholders to influence or control the organization and this influence depends on the degree of organization dependency on stakeholders (Kolk and Pinkse, 2006).

Based on the previous studies, stakeholders as organization resources can affect firms' outcomes. For example, Awan, Kraslawski, and Huiskonen (2017) examine the relationship between stakeholder pressure and adoption of sustainable supply chain practices and the impact on sustainability performance. The results showed that stakeholders' pressure can affect sustainability performance through sustainable supply chain practices. Kowalczyk (2019) studied the effect of stakeholders' pressure on corporate social responsibility in the construction industry in Poland and find that stakeholder pressure is the most effective factor in CSRpractice. Helmig, Spraul, and Ingenhoff (2016) test a link between stakeholders' pressure, CSR and market performance and find the there is an indirect effect between these variables. Brammer and Millington (2004) indicate that the type of managerially perceived stakeholder pressures affects the allocation of internal responsibility for the management of corporate giving. The empirical results of the study of Lez-Benito and Gonzalez-Benito confirm the effect of management's values and reveal that part of this effect is channeled through the influence of these values in the perception of environmental pressure. Garcés-Ayerbe, RiveraTorres, and Murillo-Luna (2012) indicate that stakeholders pressure effect in the degree of proactive environmental strategy and this relationship moderated by competitive advantages. Although some studies assess the effect of stakeholder's pressure on different dimensions of performance, none of them study the role of the perceived economic crisis in the relationship between stakeholder pressure and organizational performance. So, this study aims to cover this research gap by study the effect of stakeholder pressure on organization performance by considering the perceived economic crisis.

This paper is structured as follows. It opens with a general discussion of stakeholders' pressure and the hypotheses are presented. This section is followed by the conceptual model, the methodology and the analysis of empirical findings. Finally, the paper outlines the conclusions.

\section{Literature and Hypothesis Development}

\subsection{Stakeholder Pressure and Firm Performance}

Organizations face institutional laws in their work that they have to follow to gain legitimacy and survival (Buhrman, 2011). These institutional laws are sometimes referred to as institutional pressures, and some authors describe the various institutional pressures that organizations face. Most studies have considered institutional pressures, including regulatory, social norms, professional norms, and imitation, to claim that various benefits are arising from observing the aforementioned institutional pressures. The benefits include achieving stability, legitimacy, social support, internal and external commitment, access to resources, and recruitment of personnel. The central argument of institutional theory is that an organization adopts practices that are acceptable and legitimate in a particular setting or "organizational context", which is usually due to coercive, imitative, and normative pressures toward shared structures and processes it moves (Li, Daniel, and Ding, 2013). The stakeholder pressure is also considered as one of the institutional pressures, in this regard, organizations have their internal characteristics to match the expectations of key stakeholders in the environment. At the same time, this assessed whether the organizational changes in the public sector are consistent with the previous organizational institutional perspective (Ashworth, Boyd, \& Delbridge, 2005; Gichuke and Okello, 2015).

Because of the importance of institutional pressure on firms' decisions, some scholars studied the effect of institutional pressure on firms' activities. For example, Gichuke and Okello (2015) show that social normative and professional normative pressures affect strategic responses of 
public universities in Nakuru County. Konings et al. (2002) show that domestic competitive pressure is associated with higher firm performance in Poland irrespective of the ownership structure of firms. Chu et al. (2017) show that normative pressure and mimetic pressure affect environmental performance and operational performance through green supply chain management and social capital dimensions but coercive pressure hasn't a significant effect on environmental performance and operational performance. In their study, Moon and Bae (2011) show that the influence of state-level institutional pressure on participation in the ESBs program is weak relative to that of firms' organizational attributes.

Based on the previous studies about institutional pressure and firms' different outcomes, we can say that stakeholders' pressure can affect firm performance in terms of innovation and sale growth. So, we propose this contrasting hypothesis:

H1: Stakeholders' pressure affects firm performance.

\subsection{The Moderating Role of Perceived Economic Crisis}

The economic and financial crisis is a good example of the sudden shock in the corporate environment where organizations are changing their goals (Pollard and Hotho, 2006). For many organizations, this crisis environment may seem threatening, but for some, it is time to seize opportunities and expand. In such circumstances, some companies believe that they have sufficient opportunities that may lead them either to maintain their competitive advantage or to gain a new position and good relationship with competitors or suppliers (Wan and Yiu, 2009). So, we can say that the perceived economic crisis affects the relationship between stakeholders' pressure and firm performance. Thus, we propose this contrasting hypothesis:

$\mathrm{H} 2$ : Perceived economic crisis can moderate the effect of stakeholder's pressure on firm performance

Figure 1. Shows the research model of this study, in which stakeholders pressure directly affects firm performance and perceived economic crisis moderates this relationship.

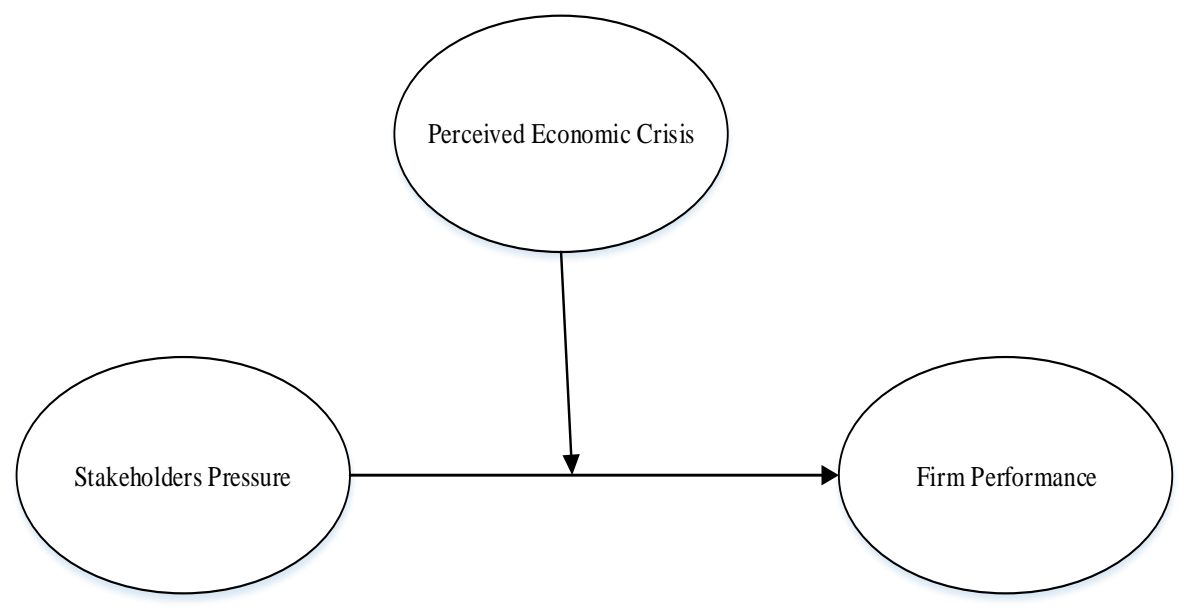

Figure1. Conceptual model

\section{Method}

\subsection{Participants and Sample}

The population of the study consisted of all firms listed in the Tehran stock exchange, which from them a sample was selected based on the Cochran formula with a finite statistical population. The number of firms was 454 with several 208 firms were selected as sample. The numbers of 220 copies of the questionnaires and a cover letter explaining the purpose of the study were sent to each of the firms. A total of 213 questionnaires were returned, which 
represented a response rate of 96 percent. The numbers of 208 accuracy questionnaires were analyzed.

\subsection{Instrument and measures}

The questionnaire consisted of 5 items covering the stakeholder's pressure (items of 1-5), 6 items for firm performance (items of 6-11) and 5 items for perceived economic crisis (items of 12-16). The stakeholder's pressure was measured based on the study of Sarkis, Gonzalez-Torre, and Adenso-Diaz (2010), the firm performance was measured using Tajvidi and Karami (2017), and perceived crisis was measured using a researcher-made questionnaire.

\section{Results}

\subsection{Descriptive Statistics}

The descriptive statistics for the research constructs in the conceptual model and the bivariate correlations between them are shown in Table 1. This bivariate correlation analysis has been carried out to test the correlations between the independent variables indicated as a need for an SEM-type analytical approach to test the hypotheses.

Table 1.

Descriptive Statistics and Correlation Analysis

\begin{tabular}{lccccccc}
\hline Variable & Mean & $\begin{array}{c}\text { Std. } \\
\text { Deviation }\end{array}$ & $\begin{array}{c}\text { KS Test } \\
\text { Statistic }\end{array}$ & Sig. & $\begin{array}{c}\text { Stakeholders } \\
\text { Pressure }\end{array}$ & $\begin{array}{c}\text { Firm } \\
\text { performance }\end{array}$ & $\begin{array}{c}\text { Perceived } \\
\text { Crisis }\end{array}$ \\
\hline Stakeholders Pressure & 3.326 & 0.612 & 0.163 & 0.917 & 1 & & \\
Firm performance & 3.154 & 0.516 & 0.217 & 0.873 & $.45^{* *}$ & 1 & 1 \\
Perceived Crisis & 4.321 & 0.405 & 0.113 & 0.952 & $-.326^{* *}$ & $-.618^{* *}$ & 1 \\
\hline
\end{tabular}

\subsection{Path Analysis}

To test the research hypotheses, we used PLS software to investigate the causal relationships among the variables. The factor loading, composite constructs reliability (CR) and average variance extracted (AVE) for the scales were computed and are shown in Table 2. The results of relationship coefficients and t-values are shown in Figure 2.

Table 2.

The factor loading, CR and AVE indexes.

\begin{tabular}{|c|c|c|c|c|}
\hline Construct & Item & $\begin{array}{l}\text { Factor } \\
\text { loading }\end{array}$ & AVE & $\begin{array}{l}\text { Composite } \\
\text { reliability }\end{array}$ \\
\hline \multirow{5}{*}{$\begin{array}{l}\text { Stakeholders } \\
\text { Pressure }\end{array}$} & The client pressure & 0.762 & \multirow{5}{*}{0.714} & \multirow{5}{*}{0.926} \\
\hline & The government pressures & 0.825 & & \\
\hline & The shareholder's pressures & 0.864 & & \\
\hline & The worker's pressures & 0.907 & & \\
\hline & The ONG/society pressures & 0.860 & & \\
\hline \multirow{7}{*}{$\begin{array}{l}\text { Firm } \\
\text { Performance }\end{array}$} & Increase in market share over the past 3 years & 0.808 & \multirow{7}{*}{0.674} & \multirow{7}{*}{0.925} \\
\hline & Increase in annual turnover over the past 3 years & 0.833 & & \\
\hline & Number of employees over the past 3 years & 0.895 & & \\
\hline & Achieving firm profit goals over the past 3 years & 0.844 & & \\
\hline & Having a better return on investment over the past 3 years & 0.824 & & \\
\hline & Increase in total income over the past 3 years & 0.712 & & \\
\hline & We expect to bankrupt in the not too distant future & 0.842 & & \\
\hline \multirow{4}{*}{$\begin{array}{l}\text { Perceived } \\
\text { Economic } \\
\text { Crisis }\end{array}$} & $\begin{array}{l}\text { We expect this company income to drop in the not too distant } \\
\text { future }\end{array}$ & 0.908 & \multirow{4}{*}{0.795} & \multirow{4}{*}{0.951} \\
\hline & We expect the prices of our products to decrease shortly & 0.924 & & \\
\hline & $\begin{array}{l}\text { We expect the price of raw materials to rise in the not too } \\
\text { distant future }\end{array}$ & 0.900 & & \\
\hline & We expect the price of the transports to rise shortly & 0.882 & & \\
\hline
\end{tabular}


According to the results, the factor loadings for all items were higher than 0.5 , indicating the importance of the items for explaining the variables currently associated with them. The value of the CR index for all the variables studied was higher than 0.9 and the index value of AVE was higher than 0.9 , indicating the reliability of the questionnaire for measuring the variables studied.

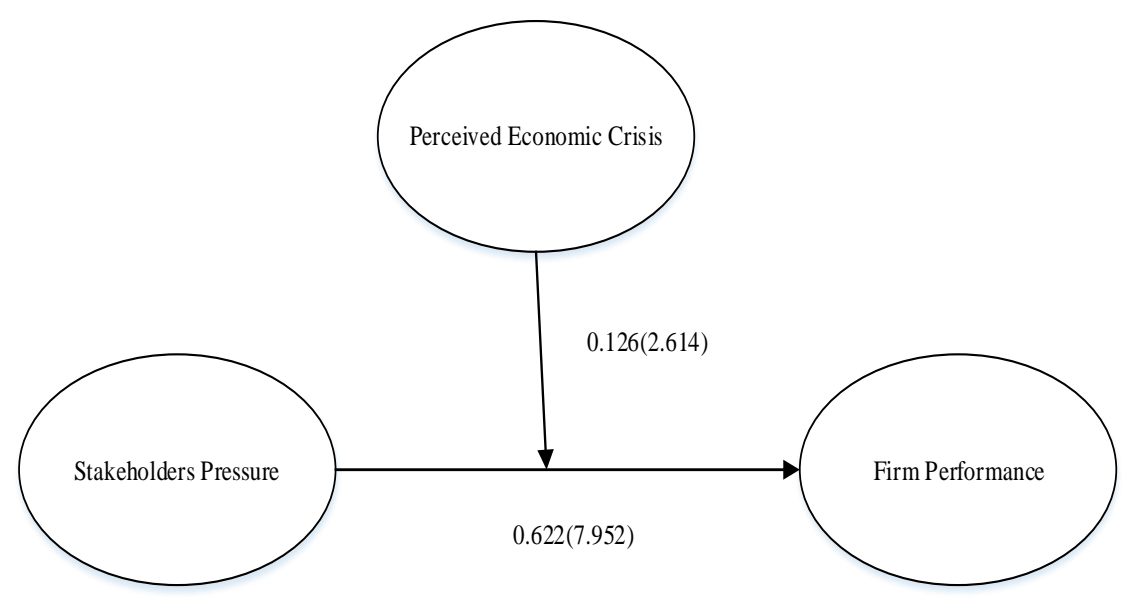

Figure 2. Final model

Based on the results, stakeholders' pressure has a positive effect on firm performance $(\beta=0.622, t-$ value $=7.952)$ and perceived economic crisis moderates this relationship $(\beta=0.126, t-$ value $=2.614)$. So, we can say the research hypothesis was accepted.

\section{Discussions and Conclusion}

According to stakeholder theory, stakeholder pressures lead to significant incentives for organizations to adopt different practices (Eesley and Lenox, 2006). Freeman (1984) defines stakeholders as any group or individual that can influence the organization's goals achievement. In the present study, the effect of stakeholders' pressure on firm performance was examined considering the moderating role of the perceived economic crisis. To investigate relationships, 208 questionnaires were collected from firms listed in the Tehran stock exchange. Structural equation modeling and PLS software were used to investigate the relationships. The results of this study showed that stakeholders pressure has a positive effect on firm performance, and perceived economic crisis reduces firm performance, and when firms believe to more likely to be in crisis, the positive effect of stakeholders' pressure on firm performance was decreased. Therefore, it can be argued that stakeholder pressure can persuade companies to pursue activities that ultimately improve their financial performance.

\section{Reference}

Ashworth R, Boyne G and Delbridge R (2007) Escape from the iron cage: Organizational change and isomorphic pressures in the public sector. Journal of Public Administration Research and Theory 19: 165-187.

Awan, U., Kraslawski, A., \& Huiskonen, J. (2017). Understanding the relationship between stakeholder pressure and sustainability performance in manufacturing firms in Pakistan. Procedia Manufacturing, 11, 768-777.

Brammer, S., \& Millington, A. (2004). Stakeholder pressure, organizational size, and the allocation of departmental responsibility for the management of corporate charitable giving. Business \& Society, 43(3), 268-295. 
Bührman, G. (2011). Institutional pressures and strategic responses: The case of the BP oil spill. Amsterdam, Netherlands: Vrije Universiteit.

Carroll, A. B., Buchholtz, A., \& Business, A. (2000). Society: ethics and stakeholder management. United States.

Chu, S. H., Yang, H., Lee, M., \& Park, S. (2017). The impact of institutional pressures on green supply chain management and firm performance: Top management roles and social capital. Sustainability, 9(5), 764.

Conner, K. R. (1991). A historical comparison of resource-based theory and five schools of thought within industrial organization economics: do we have a new theory of the firm? Journal of management, 17(1), 121-154.

Eesley, C., \& Lenox, M. J. (2006). Firm responses to secondary stakeholder action. Strategic Management Journal, 27(8), 765-781.

Famiyeh, S. (2017). Corporate social responsibility and firm's performance: empirical evidence. Social Responsibility Journal.

Freeman, R. E. (1984). Strategic Management: A Stakeholder Approach (Boston: Pitman, 1984). Jennings, in the article cited above, quotes Freeman and gives additional information concerning the influence of his work.

Garcés-Ayerbe, C., Rivera-Torres, P., \& Murillo-Luna, J. L. (2012). Stakeholder pressure and environmental proactivity. Management Decision.

Gichuke, R. K., \& Okello, B. (2015). Relationship between institutional pressures and strategic responses of public universities in Nakuru County, Kenya. International Journal of Economics, Commerce and Management United Kingdom, 3 (11): 662, 85.

Helmig, B., Spraul, K., \& Ingenhoff, D. (2016). Under positive pressure: How stakeholder pressure affects corporate social responsibility implementation. Business \& Society, 55(2), 151-187.

Jamali, D. (2008). A stakeholder approach to corporate social responsibility: A fresh perspective into theory and practice. Journal of business ethics, 82(1), 213-231.

Jawahar, I. M., \& McLaughlin, G. L. (2001). Toward a descriptive stakeholder theory: An organizational life cycle approach. Academy of management review, 26(3), 397-414.

Julian, S. D., \& Ofori-Dankwa, J. C. (2013). Financial Resource Availability and CSR Expenditures in a Sub-Saharan Economy: the Institutional Difference Hypothesis. Strategic Management Journal, 34(11), 1314-1330.

Kolk, A., \& Pinkse, J. (2006). Stakeholder mismanagement and corporate social responsibility crises. European Management Journal, 24(1), 59-72.

Konings, J., Estrin, S., Zolkiewski, Z., \& Angelucci, M. (2002). The effect of ownership and competitive pressure on firm performance in transition countries: Micro evidence from Bulgaria, Romania and Poland.

Kowalczyk, R. (2019). How Do Stakeholder Pressure Influence On CSR-Practices in Poland? The Construction Industry Case.

Kowalczyk, R. (2019). How Do Stakeholder Pressure Influence On CSR-Practices in Poland? The Construction Industry Case.

Kull, A. J., Mena, J. A., \& Korschun, D. (2016). A resource-based view of stakeholder marketing. Journal of Business Research, 69(12), 5553-5560. 
Li, F., \& Ding, D. Z. (2013). The effect of institutional isomorphic pressure on the internationalization of firms in an emerging economy: Evidence from China. Asia Pacific Business Review, 19(4), 506-525.

Moon, S. G., \& Bae, S. (2011). State-level institutional pressure, firms' organizational attributes, and corporate voluntary environmental behavior. Society \& Natural Resources, 24(11), 1189-1204.

Parmigiani, A., Klassen, R. D., \& Russo, M. V. (2011). Efficiency meets accountability: Performance implications of supply chain configuration, control, and capabilities. Journal of operations management, 29(3), 212-223.

Pfeffer, J., \& Salancik, G. R. (1978). The external control of organizations: A resourcedependency perspective Harper \& Row New York USA.

Pollard, D., \& Hotho, S. (2006). Crises, scenarios and the strategic management process. Management Decision.

Porter, M. E., \& Millar, V. E. (1985). How information gives you competitive advantage.

Sarkkaya, M., \& Özdemir, S. (2009). The changing business environment and the internet media as a stakeholder group. In The Third International Scientific Conference on Changes in Social and Business Environment, Panevezys, Lithuania (pp. 345-348).

Seuring, S., \& Müller, M. (2008). Core issues in sustainable supply chain management-a Delphi study. Business strategy and the environment, 17(8), 455-466.

Wan, W. P., \& Yiu, D. W. (2009). From crisis to opportunity: Environmental jolt, corporate acquisitions, and firm performance. Strategic Management Journal, 30(7), 791-801.

Yoon, B., \& Chung, Y. (2018). The effects of corporate social responsibility on firm performance: A stakeholder approach. Journal of hospitality and tourism management, 37, 89-96.

Yu, Y., \& Choi, Y. (2016). Stakeholder pressure and CSR adoption: The mediating role of organizational culture for Chinese companies. The social science journal, 53(2), 226-234.

Zhou, Y., Poon, P., \& Huang, G. (2012). Corporate ability and corporate social responsibility in a developing country: the role of product involvement. Journal of Global Marketing, 25(1), 45-56. 